\title{
Determinants and Consequences of Product Differentiation Strategy: Evidence from Chinese Indigenous Exporters
}

\author{
Xuenan $\mathrm{Ju}^{1}$, Lili Tong ${ }^{2}$, Zuohao $\mathrm{Hu}^{3} \&$ Baowen $\mathrm{Sun}^{1}$ \\ ${ }^{1}$ China Centre for Internet Economy Research (CCIE), Central University of Finance and Economics, Beijing, \\ China \\ ${ }^{2}$ Department of Marketing, Beijing University of Posts and Telecommunications, Beijing, China \\ ${ }^{3}$ Department of Marketing, Tsinghua University, Beijing, China \\ Correspondence: Xuenan Ju, 605 Shiyan Building, China Center for Internet Economy Research, Central \\ University of Finance and Economics, Beijing 100081, P. R. China.
}

Received: June 19, 2017

doi:10.5539/ibr.v10n9p60
Accepted: August 3, $2017 \quad$ Online Published: August 14,2017

URL: https://doi.org/10.5539/ibr.v10n9p60

\begin{abstract}
Focusing on Chinese indigenous exporters, this research investigates the antecedents of the product differentiation strategy (PDS), and its impacts on export performance with the moderating role of export target markets. Drawing from the contingency theory and strategy management framework, the authors adopt structural equation modeling (SEM) to analyze the survey data collected from 195 Chinese indigenous exporters. The empirical results suggest that the PDS positively affects Chinese exporters' performance. Firms are more likely to adopt the PDS when innovation and marketing capabilities are high and when they export to turbulent markets. The positive impact of the PDS on export performance is stronger when firms export to developed (vs. other emerging) markets. With the unique perspective from emerging markets, the authors theoretically discuss and empirically examine the antecedents-PDS-performance link. This research suggests that Chinese export firms rationally adopt the PDS and actively cultivate technology and inno vation capability and international marketing competence on export businesses.
\end{abstract}

Keywords: Product Differentiation Strategy (PDS), emerging markets, export performance, marketing strategy, target markets

\section{Introduction}

Investigating emerging market firms' product strategies' impact on export performance is a urgent and remarkable topic in international market researches. On the one hand, the rapid growth and increasing base makes emerging markets more influential on the worldwide economy. One the other hand, because of various industrial standards and economic foundations across nations, emerging markets have more widely different understandings and choices on export product strategies compared to other markets. By now, researches regarding product strategy's impact on performance for exporters from emerging markets still call for further attention.

As one of the most essential marketing elements for both marketing practitioners and academics, product strategy is equally, if not more, important in the context of emerging market firms' export business. Due to the critical role to a firm's success, export product strategy has drawn the attention of a considerable number of researchers as a key determinant of export performance. Despite extensive research into the antecedents and consequences of export product strategies, the results remain inconclusive. The variety on the country and cultural level and the various measurements of performance add more complexity to the product-performance relationship for international markets.

Product differentiation strategy (hereinafter, PDS) refers to firms that provide different or superior quality of products (or services) in order to improve consumers' satisfaction and loyalty, and hence, firm's profitability and performance. One of the most representative firms is Huawei, who succeeds in providing high-quality products by adopting a differentiation strategy and making a substantial commitment to R\&D both home and abroad. However, the PDS is not without limitations. The most significant limitation is that the PDS amplifies firms' vulnerability to fluctuation in international markets. Consequently, firms that over-relying on the PDS are hard to 
cultivate a sustainable course on international markets.

Since the empirical results in the existing literature are inconclusive, and the complex nature of the impact of the PDS on performance for firms from the emerging markets, this paper inspects the determinants of PDS adoption and its impact on export performance in the context of emerging markets. Our paper contributes to the empirical perspective of the relation between the PDS and export performance. In addition, our paper provides a better investigation of the different impacts of the PDS in various international markets. In specific, our paper plans to discuss the following questions:

(1) Whether the PDS improve or harm export performance for firms from emerging markets?

(2) What antecedents lead emerging market firms to adopt the PDS?

(3) What factors moderate the impact of the PDS on export performance?

The rest of our paper proceeds as follows. We outline the conceptual and theoretical background of the existing studies in section 2. In the following section, we present the research framework and our key hypotheses. We describe our research methodology and data sample in section 4. In section 5 we report data analysis and key results of our empirical model. Finally, we provide practical implications and the future research directions.

\section{Theoretical Background}

\subsection{Definition and Implication of the PDS}

The concept of the PDS stems from industrial economic theory, which concludes two major approaches of earning superior return compared to competitors: differentiation strategy and cost leadership strategy. Differentiation strategy emphasizes distinctive capabilities and unique experiences compared to competitors, while cost leadership focuses on lower production and distribution costs to create higher margins (Porter, 2011). Constraint by technological and capital reasons, many established firms prefer PDS when they enter into international markets. Advanced innovative power and technological leadership helps them to produce high-end products. In addition, because established exporters prefer to provide the market with high value-added products, they tend to adopt differentiation strategy when they compete internationally. Therefore, the PDS requires firms have sufficient capital, superior management and experience of international business. In the particular circumstance of globalization, exporters should plan the international strategies from a synergistic perspective. The adoption of the PDS can help exporters acquire advantageous position and grow in a sustainable manner.

\subsection{Conceptual Framework}

As figure 1 indicates, both external antecedents (export market's turbulent intensity and institutional pressure) and internal factors (export product's innovation and international marketing competence) influence an exporting firm's strategic decision on the PDS adoption. Combined with the RBV, Cavusgil and Zou (1994) argue that both the particular strategy designed for international markets and capacity to conduct the international marketing strategy determine export performance. Therefore, conceptual framework of our study indicates that the PDS and international marketing competence influence a firms' export performance together.

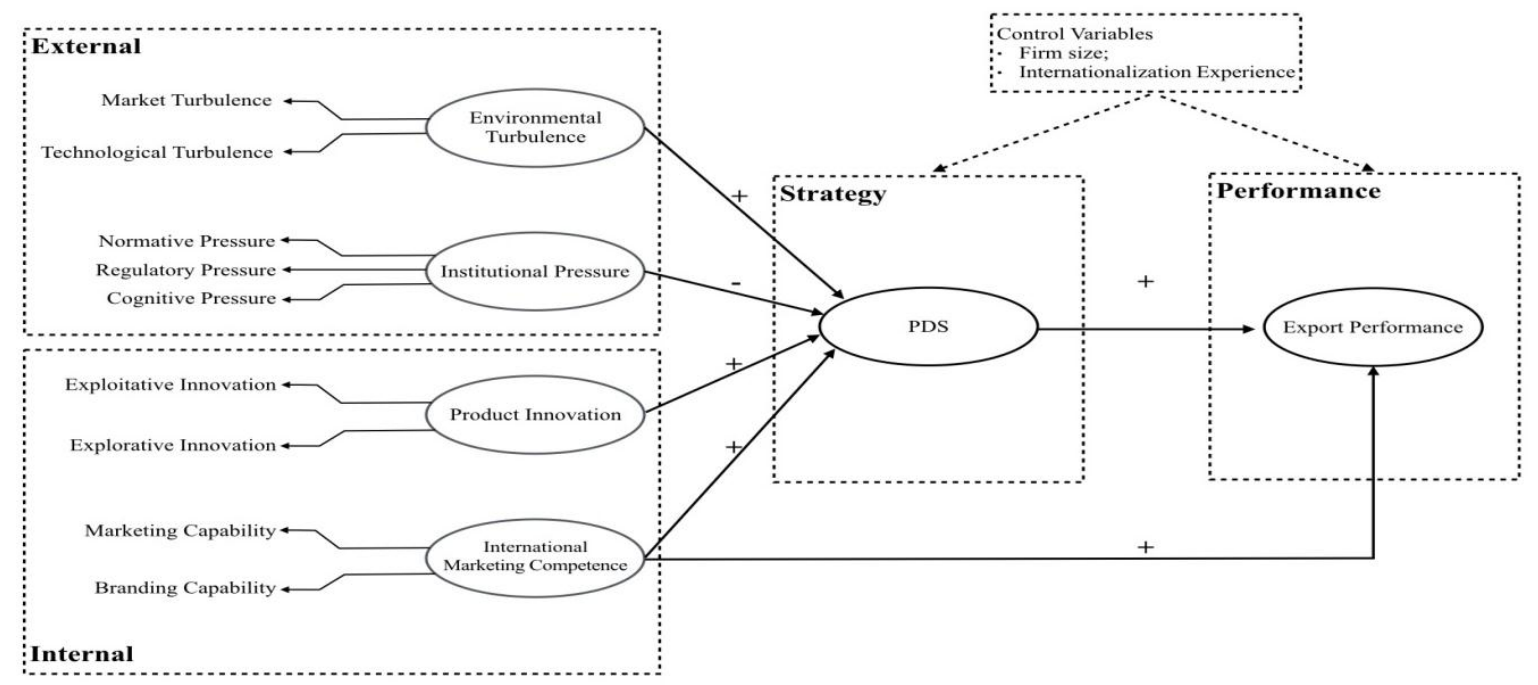

Figure 1. Conceptual Framework: Antecedents and Consequences of the PDS 


\section{Hypothesis Development}

\subsection{Antecedents of the PDS}

Market Turbulence Market turbulence describes the degree to which an international market changes, including changes in market environment and industry technology (Jaworski \& Kholi, 1993; Lages \& Montgomery, 2004). As one of the most important environmental factors in the field of PDS studies, market turbulence shows significant and direct impact on exporters' international strategies (Powers \& Loyka, 2010; Tan \& Sousa, 2011). The change in competitors, pricing and technology improvement are different sources of market turbulence.

Some studies suggest that with the escalation of market turbulence, firms will face the pressure and incentive to adopt PDS to differentiate their products or services from their competitors, thus maximizing market orientation and customer value. Therefore, market turbulence is positively related to the PDS adoption (e.g., Lages et al., 2008). However, other researchers believe that in the volatile environment, firms will emphasize the economies of scale and cost advantages, so the market turbulence will promote the implementation of standardization strategy (e.g., Powers \& Loyka, 2007).

In this paper, we suggest that in turbulent international markets, the adoption of cost-leading strategies will exacerbate the potential risks associated with product homogenization. Instead, by providing unique products/services that can effectively distinguish themselves from their competitors. The PDS not only improve product quality, but also helps firms effectively shape their brand image. Therefore, this paper argues that as the market turbulence is constantly escalating, firms from emerging markets are more likely to adopt PDS. Thus, we propose that:

H1. Firms from emerging markets are more likely to adopt the PDS when the turbulence in (1) the export market and (2) industry technology is high.

Institutional pressure Based on the literature review, the current studies regarding institutional pressure in the field of international marketing strategy are mainly focused on the following three dimensions: regulatory pressure, formative pressure and cognitive pressure. Empirical studies show that institutional pressure have significant impact on firms' international marketing strategies as well as export performance ( $Q u, 2007$; Cavusgil $\&$ Zou, 1994). We propose that when institutional pressures from international markets continue to rise, firms need to allocate more resources in adapting local institutional environments. Stricter institutional requirements also consume the resources that the firm allocates for the international market, so the firm will take a more efficient organizational structure to compensate for the loss of efficiency, and thus tend to be more cost-effective rather than differentiation. This tendency is particularly evident in firms from emerging markets. Unfavorable research and development capabilities make the internationalization of emerging market firms do not have enough resources to meet the local institutional environment pressure while providing higher value-added products at the same time, so this study argues that with the institutional environment pressure rises, the tendency to choose the PDS will be gradually reduced.

Therefore, we propose the second hypothesis:

H2. Firms from emerging markets are less likely to choose the PDS when institutional pressure of international market is intense.

Product innovation Product innovation is one of the key elements of international business because they influence multiple aspects of international markets (Myers and Cavusgil 1996). We suggest that product innovation is an effective means to distinguish exporting firms from their international competitors. Since the differentiation strategy means that the products/services offered have higher added value, are perceived as unique and excellent from consumers' perception, and can bring more benefits to consumers. Therefore, product innovation is positively related with PDS adoption. Existing researches suggest that innovation not only plays as an important source of firm's creativity, but also enhance export performance through the process in collecting, understanding and applying new knowledge and new information (Aragón-Correa, García-Morales, \& Cordón-Pozo, 2007). In addition, the process of innovation will strengthen learning and application of new ideas and new methods to more effectively meet customer needs (Kaleka \& Berthon, 2006). Therefore, we propose that product innovation can positively affect emerging market firms' adoption in PDS.

H3. Firms from the emerging market are more likely to adopt the PDS if their product innovation capability in (1) exploitation and (2) exploration is high.

International Marketing Competence International marketing competence plays a critical role on both the choice and implementation of export strategy. As one school of marketing competence emphasizes capabilities and resources which support exporters to conduct business internationally (Zou \& Cavusgil, 2002), other 
scholars claim that international marketing competence is reflected in each aspects of marketing mix (e.g., price, product, promotion and distribution) to the international circumstance (Moen \& Servais, 2002). Despite the different emphasis, existing literature agrees that superior international marketing competence enhances firms' export performance.

We suggest that the effect of firms' international marketing competence consist of three as pects: (1) identify export market characteristics; (2) develop appropriate international marketing strategies; and (3) effectively conduct the chosen strategies. In addition, international marketing competence allows firms to respond to market turbulences by collecting and analyzing information in a timely manner.

As a matter of fact, there is a significant number of firms from emerging markets adopt differentiation strategy on international markets. We suggest that the PDS is appropriate if this strategy complies with the firms' own features. Moreover, compared with cost-leadership strategy, exporting firms are more likely to adopt the PDS if they possess strong brand power internationally. Therefore, we propose that:

H4. Firms from emerging markets are more likely to choose the PDS if their (1) international marketing capability and (2) international branding capability are high.

H5. Firms from emerging markets are more likely to achieve superior export performance if their international marketing capability and (2) international branding capability are high.

\subsection{Performance Effect of the PDS}

Export performance is one of the most dominant consequences of export strategies. However, international marketing studies adopt various measurements of performance. In current study, we use economic indicators (sales growth and profitability) and strategic indicators (export goal achievement and management satisfaction) to measure a firm's performance on international markets. As a matter of fact, export product strategy's impacts on export performance are inconsistent, with some researchers suggest that cost-leadership strategy enhances a firm's export performance in terms of sales volume, sales growth and profitability (e.g., Lado, Martínez-Ros, \& Valenzuela, 2004) and others find that differentiation strategy is desirable to a firm's performance in terms of sales growth, export intensity, profitability, degree of internationalization, and satisfaction with export performance (e.g., Cooper \& Kleinschmidt, 1985; Brouthers \& Xu, 2002). Additionally, some studies also find non-significant relationships between product competitiveness and export performance (Albaum \& Tse, 2001).

We propose that the PDS positively affects emerging market firms' export performance. On the one hand, the overweight emphasis on prices due to competition homogeneity, in turn, exacerbates the greater reliance on cost-leadership strategies. However, this price-sensitive environment also limits the potential for higher profit margins and more sustainable development. At the same time, the advantages of low labor costs, low raw material cost are gradually disappearing in emerging markets. Therefore, firms from emerging markets should provide differentiated products/services to make up for the loss of competitive advantage (Ghauri \& Cateora, 2010). On the other hand, the PDS can increase firms' profitability from a long-term point of view (Yap \& Yazdanifard, 2014). In addition, the PDS can enhance firms' export performance by shaping a superior brand image, improving consumer satisfaction and loyalty and increasing brand premium. Therefore, the authors propose that:

H6. The PDS positively relates to export performance of firms from emerging markets.

\subsection{Moderating Effects of Exports Markets}

The particular characteristics of emerging markets allow exporters to trade with both developed and de veloping markets. However, these two markets are different in the following aspects. First, according to the criteria of defining developing and developed, these two markets have various levels of industrial foundations and economic power. Strong purchasing power allows consumers to choose multiple preferred features rather than only focusing on price. As a result, the impact of the PDS on firms' export performance is more significant in developing markets compared to that in developed ones. In addition, instead of product alone, consumers from developed-market tend to comprehensively evaluate various characteristics such as service and customization. Hence, we propose that:

H7. Compared to developing markets, the positive impact of the PDS on export performance is more salient if firms export to developed markets.

\section{Methodology}

\subsection{Field Interviews}

We first translate the English questionnaire into Chinese based on existing literature. To better investigate the 
relationship between the PDS and export performance, we conduct in-depth field interviews with twelve executive managers of export business from China. Integrating their expertise and experience from export business operations, the interviewees provide useful implications on the accuracy of questionnaire and the contents of key constructs. In the following step, we invite three academic professionals from the marketing field to evaluate our questionnaire in order to ensure its reliability and validity from the academic perspective (Zikmund, Babin, \& Griffin, 2012).

\subsection{Questionnaire Development and Measures}

Basing on existing literature and filed interviews, we design a standardized questionnaire. Furthermore, we translate the Chinese questionnaire back into the English and interview 20 MBA students about the expression of its contents. After revising the expressions and other amendments, our questionnaire includes six segments: measuring the PDS, export performance, market turbulence, institutional pressure, product innovation and international marketing competence. In the last section of the questionnaire, we also collect firm-related data such as firm size, age, export intensity and so on.

The PDS We follow Cavusgil and Zou (1994) and Moen and Servais (2002) to measure the PDS in four ways: "customers can easily recall our products", "our products are different from all other products in terms of attributes", "Our products are different from all other products in terms of overall perceived quality" and "we pursue a differentiation strategy by products." These four aspects cover the main concept of the PDS and its evaluation.

Market Turbulence The authors follow Jaworski and Kohli (1993) and Jayachandran et al. (2005) to measure the degree of turbulence in market and technology respectively. Market turbulence is measured by "frequent changes in customer preferences", "our customers tend to look for new product all the time", "new customers tend to have product-related needs that are different from those of our existing customers"; while technological turbulence is measured by "the technology is our industry is changing rapidly" and "technological changes provide big opportunities in our industry".

Institutional pressure Existing literature describes the institutional pressure with three dimensions: (1) cognitive pressure (2) regulatory pressure; and (3) normative pressure. The authors follow Qu (2007) and Yiu \& Shige (2002) to measure these constructs.

Product innovation Following the discussions of Jimenez and Valle (2011) and Zhou and Wu (2007), we develop scales to measure product innovation from two dimensions: exploitive innovation (use and refine existing knowledge and skill) and explorative innovation (search and pursue completely new knowledge and skill).

International marketing competence According to existing literature, the construct of "international marketing competence" is measured in two ways: the capabilities and resources that allow firms to operate on international markets), and the competence of the marketing mix (e.g., price, product, promotion and distribution) to the international field. In this paper, we follow the latter stream (Moen \& Servais, 2002) to measure a firm's international marketing competence from the perspective of marketing mix internationalization.

Export performance As discussed above, we measure a firm's export performance both economically (sales growth and profitability) and strategically (export goal achievement and management satisfaction) (Reimann et al., 2010; Morgan, Katsikeas, \& Vorhies, 2012).

\subsection{Data and Sample}

We choose firms from China to collect data and conduct empirical analysis. We believe Chinese exporters are appropriate to our research because their vast export volume and fast growth in recent years. As the first step, we choose samples from the Directory of Foreign Economic and Trade Enterprises of China (2013-2014) (a database from the Chinese Department of Foreign Trade Ministry of Commerce) and Alibaba (the largest internet-based e-commerce company in China). We choose firms according to three criteria: (1) firms must export to international markets; (2) firms must have more than 50\% Chinese ownership; and (3) firms must have complete contact information. We received 195 usable questionnaires at the end of survey. Our samples distribute mainly across four industrial categories: computer, electronic and optical products (ISIC 26), textiles and wearing apparel (ISIC 13,14), chemicals and chemical products (ISIC 20), and manufacturing of machinery and equipment (ISIC 28). Table 1 summarizes our sample characteristics in detail. 
Table 1. Sample firm description (Adjusted industry affiliation according to ISIC)

\begin{tabular}{|c|c|c|c|c|c|c|c|}
\hline \multicolumn{2}{|c|}{ Size (employee number) } & \multirow{2}{*}{$\begin{array}{l}\begin{array}{l}\text { Sales Volume } \\
\text { million) }\end{array} \\
300 \text { or less }\end{array}$} & \multirow{2}{*}{$\begin{array}{l}(\mathrm{rmb} \\
22 \%\end{array}$} & $\begin{array}{l}\text { Computer, electronic and } \\
\text { optical products (ISIC 26) }\end{array}$ & \multirow{2}{*}{$\begin{array}{l}33 \% \\
36 \% \\
\end{array}$} & \multicolumn{2}{|c|}{ Export Target Markets* } \\
\hline 200 or less & $37.4 \%$ & & & $\begin{array}{l}\text { Textiles and Wearing } \\
\text { Apparel (ISIC 13, 14) }\end{array}$ & & $\begin{array}{l}\text { Developed } \\
\text { countries }\end{array}$ & $47.1 \%$ \\
\hline $201-500$ & $20.6 \%$ & $300-3000$ & $44 \%$ & $\begin{array}{l}\text { Chemicals and chemical } \\
\text { products (ISIC 20) }\end{array}$ & $20 \%$ & $\begin{array}{l}\text { Other emerging } \\
\text { countries }\end{array}$ & $52.9 \%$ \\
\hline $501-1000$ & $18.1 \%$ & 3000 or more & $34 \%$ & $\begin{array}{l}\text { Manufacturing of } \\
\text { machinery and equipment } \\
\text { (ISIC 28) }\end{array}$ & $11 \%$ & Total & $100 \%$ \\
\hline $1001-5000$ & $14.8 \%$ & Total & $100 \%$ & Total & $100 \%$ & & \\
\hline $\begin{array}{l}\text { More than } \\
5000\end{array}$ & $9.1 \%$ & & & & & Export Products & \\
\hline Total & $100 \%$ & Export Intensity & & Geographical Distribution & & Consumer goods & $43.2 \%$ \\
\hline $\begin{array}{l}\text { Export } \\
\text { (years) }\end{array}$ & Experience & $\begin{array}{l}10 \% \text { or less } \\
10 \%-30 \%\end{array}$ & $\begin{array}{l}23 \% \\
33 \%\end{array}$ & $\begin{array}{l}\text { Zhejiang } \\
\text { Guangdong }\end{array}$ & $\begin{array}{l}21.9 \% \\
19.4 \%\end{array}$ & $\begin{array}{l}\text { Industrial goods } \\
\text { Total }\end{array}$ & $\begin{array}{l}56.8 \% \\
100 \%\end{array}$ \\
\hline 5 or fewer & $52 \%$ & $50 \%-70 \%$ & $19 \%$ & Jiangsu & $13.5 \%$ & & \\
\hline $5-10$ & $35 \%$ & $70 \%$ or more & $25 \%$ & Hebei & $13.5 \%$ & & \\
\hline $11-15$ & $3.2 \%$ & Total & $100 \%$ & Beijing & $12.3 \%$ & & \\
\hline 15 or more & $9.8 \%$ & & & Others & $19.4 \%$ & & \\
\hline Total & $100 \%$ & $\begin{array}{l}\text { Primary } \\
\text { Affiliation }\end{array}$ & Industry & Total & $100 \%$ & & \\
\hline
\end{tabular}

*Developed countries: $\$ 12,746$ GNI per capita or more; Emerging countries: $\$ 12,746$ per capita or less (The World Bank, 2015 fiscal year ${ }^{1}$ ).

Identify "the country/market your most important clients/markets located in" if export to both developed and emerging markets simultaneously.

Survey data tend to suffer from some bias that could undermine the accuracy and efficiency of the estimation. Common method bias and nonresponse bias are representative bias of survey data. Common method bias refers to "variance that is attributable to the measurement method rather than to the constructs the measures are assumed to represent" (Podsakoff \& Organ, 1986). While nonresponse bias comes from respondents differ in meaningful ways from nonrespondents (Armstrong and Overton, 1977). We test these biases and the results suggest that both bias are not significant. Hence, Common method bias and nonresponse bias are not severe challenges to the following analysis. We use a structural equation model (SEM) to conduct the empirical analysis. The detailed information of the bias tests is listed in appendix.

\section{Results}

\subsection{Measure Assessment}

Table 2 summarizes our data in terms of construct means, standard deviations, and the correlation matrix between the constructs. The AVE (average variance extracted) of each construct is reported on the diagonal.

Table 2. Means, standard deviations, and correlations among latent constructs (AVE values on diagonal)

\begin{tabular}{|c|c|c|c|c|c|c|c|c|c|c|c|c|c|}
\hline Construct & Mean & SD & mtur & ttur & rprs & fprs & cprs & linno & kinno & mcap & $\begin{array}{l}\mathrm{c} \\
\mathrm{ip}\end{array}$ & pds & per \\
\hline Market Turbulence (mtur) & 4.27 & 1.40 & 0.64 & & & & & & & & & & \\
\hline $\begin{array}{r}\text { Technological Turbulence } \\
\text { (ttur) }\end{array}$ & 6.11 & 1.73 & 0.24 & 0.74 & & & & & & & & & \\
\hline Regulatory pressure (rprs) & 5.48 & 1.38 & 0.14 & 0.16 & 0.83 & & & & & & & & \\
\hline Normative pressure (fprs) & 4.59 & 0.89 & 0.26 & 0.19 & 0.67 & 0.85 & & & & & & & \\
\hline Cognitive pressure (cprs) & 4.49 & 0.92 & 0.07 & 0.06 & 0.54 & 0.69 & 0.82 & & & & & & \\
\hline $\begin{array}{r}\text { Exploitative Innovation } \\
\text { (linno) }\end{array}$ & 5.14 & 1.15 & 0.14 & 0.28 & 0.31 & 0.48 & 0.44 & 0.72 & & & & & \\
\hline $\begin{array}{r}\text { Explorative Innovation } \\
\text { (kinno) }\end{array}$ & 4.85 & 1.23 & 0.17 & 0.33 & 0.38 & 0.51 & 0.42 & 0.60 & 0.73 & & & & \\
\hline Marketing Capability (mcap) & 4.58 & 1.10 & 0.24 & 0.27 & 0.62 & 0.44 & 0.34 & 0.45 & 0.47 & 0.70 & & & \\
\hline Branding Capability (bcap) & 4.06 & 1.42 & 0.09 & 0.33 & 0.25 & 0.33 & 0.29 & 0.32 & 0.32 & 0.55 & 0.70 & & \\
\hline $\begin{array}{r}\text { Product Differentiation } \\
\text { Strategy }(p d s)\end{array}$ & 4.69 & 1.35 & 0.15 & 0.26 & 0.16 & 0.26 & 0.23 & 0.29 & 0.27 & 0.32 & 0.28 & 0.65 & \\
\hline Export performance (per) & 4.82 & 1.18 & 0.16 & 0.31 & 0.16 & 0.23 & 0.22 & 0.33 & 0.28 & 0.37 & 0.32 & 0.24 & 0.87 \\
\hline
\end{tabular}

\footnotetext{
${ }^{1}$ http://data.worldbank.org/topic/economy-and-growth
} 
Table 3 summarizes the key results of Confirmatory Factor Analysis (CFA) and standardized factor loading of each construct.

Table 3. Measurement models and Confirmatory Factor Analysis (CFA) results

\begin{tabular}{llll}
$\alpha$ & Cronbach's alpha & Cronbach (1951) \\
$\rho_{\mathrm{vc}(\eta)}$ & Average & Variance & Fornell and Larcker \\
& Extracted (AVE) & $(1981)$ \\
$\rho_{(\eta)}$ & Composite Reliability & Bagozzi (1980) \\
\hline
\end{tabular}

\begin{tabular}{lrrr}
\hline & $\alpha / \rho_{\mathrm{vc}(\eta)} / \rho_{(\eta)}$ & $\begin{array}{c}\text { Standardized } \\
\text { Loading }\end{array}$ & Z-value \\
\hline Environmental Turbulence & & & Jaworski \& Kholi \\
(1993)
\end{tabular}

Market Turbulence

In our kind of business, customers' product preference change quite a

bit over time.

Our customers tend to look for new product all the time

New customers tend to have product-related needs that are different

from those of our existing customers.

\section{Technological Turbulence}

The technology in our industry is changing rapidly

Technological changes provide big opportunities in our industry

\section{Institutional pressure}

\section{Regulatory pressure}

The local government in the international market severely punish operating practices that violate laws and regulations Local governments in the international market protect the interests of market players through strict law enforcement The local government in the international market actively advocates that enterprises should comply with laws and regulations

Local governments in the international market respond quickly to corporate irregularities reflected in the public
$.81 / .64 / .84$
.85

13.82

$.84 \quad 13.58$

$.70 \quad 9.34$

$.82 / .74 / .85$

$.96 \quad 10.54$

$.75 \quad 5.92$

Yiu \& Shige (2002)

$.94 / .84 / .95$
$93 \quad 15.59$

$.92 \quad 15.80$

$.92 \quad 16.22$

\begin{tabular}{|c|c|c|}
\hline$\alpha / \rho_{\mathrm{vc}(\eta)} / \rho_{(\eta)}$ & $\begin{array}{r}\text { Standardized } \\
\text { Loading } \\
\end{array}$ & Z-value \\
\hline Normative pressure & & \\
\hline $\begin{array}{l}\text { We can learn about normative codes from local industry or } \\
\text { professional associations }\end{array}$ & .89 & 10.83 \\
\hline $\begin{array}{l}\text { The social corporate responsible business philosophy is highly } \\
\text { recommended by the international public }\end{array}$ & .84 & 14.08 \\
\hline $\begin{array}{l}\text { The public in the international market highly appreciates the responsible } \\
\text { treatment of stakeholders }\end{array}$ & .88 & 15.09 \\
\hline $\begin{array}{l}\text { It is highly influential if we follow all kinds of industry rules on the } \\
\text { international market }\end{array}$ & .77 & 12.45 \\
\hline Cognitive pressure $\quad .88 / .82 / .93$ & & \\
\hline $\begin{array}{l}\text { We believe that international firms should follow the local laws and } \\
\text { regulations of the international market }\end{array}$ & .92 & 13.80 \\
\hline $\begin{array}{l}\text { We believe that international firms should have social responsibility for } \\
\text { their international markets }\end{array}$ & .84 & 13.90 \\
\hline $\begin{array}{l}\text { We believe that international firms should create value for customers in the } \\
\text { international market }\end{array}$ & .95 & 14.14 \\
\hline
\end{tabular}

Product Innovation

Jimenez \& Valle

(2011)

\section{Exploitative Innovation}

$.91 / .72 / .91$

Upgraded current knowledge for familiar products

Invested in exploiting mature technologies that improve the productivity of 
current innovation operations

Enhanced abilities in searching for solutions to customer problems that are

near to existing solutions.

Upgraded skills in product de velopment processes in which

the firm already

possesses rich experience.

\section{Explorative Innovation}

Acquired manufacturing technologies and skills entirely new to the firm

Learned product development skills and processes entirely new to the industry.

Learned totally new skills in funding new technology and training $\mathrm{R} \& \mathrm{D}$

personnel.

Strengthened innovation skills in areas where it has no prior experience

$.87 / .73 / .92$

\begin{tabular}{|c|c|c|c|}
\hline & .83 & 13.91 & \\
\hline & .86 & 14.67 & \\
\hline & .79 & 12.86 & \\
\hline & .93 & 10.54 & \\
\hline$\alpha / \rho_{\mathrm{vc}(\eta)} / \rho_{(\eta)}$ & $\begin{array}{r}\text { Standardized } \\
\text { Loading }\end{array}$ & Z-value & Source \\
\hline
\end{tabular}

Moen \& Servais

(2002)

\section{Marketing Capability}

We can set price efficiently on the export markets.

We can build and manage our distribution network effectively.

We can effectively advertise and promote our product on export markets.

We can adopt differentiation strategy by marketing approaches.

$.90 / .70$

$$
1.90
$$

Ability to carry out brand building in the international market

Ability to develop overseas markets for our brands

\section{Export Performance}

$.94 / .87 / .96$

Reimann et al.

(2010)

Growth rate of sales volume.

Profitability of export business

Export business achieved our anticipated export strategic goal

Our firm is satisfied with the management of export performance

Product Differentiation Strategy (PDS)

$.86 / .65 / .90$

Cavusgil \& Zou

(1994)

Moen \& Servais

(2002)

Our product has a high reputation in the international market

Our product is significantly different from other products in terms of image and design

Our product is significantly different from other products in terms of function and quality

We adopt a product differentiation strategy on international markets

The results of composite reliability test show that constructs' CR values $\left(\rho_{(\eta)}\right)$ are all above .70 , indicating that the measurement of our CFA model is reliable (Bagozzi, 1980; Hair, Black, Babin \& Anderson, 2009). We use Cronbach's alpha to check internal consistency within each construct. The average loading size was .75, suggesting that our CFA model has a good convergence validity. Furthermore, we compare correlations and the AVE value $\left(\rho_{v c_{(\eta)}}\right)$ to evaluate discriminate validity. All AVE values in our CFA model are above .60 and higher 
than the squared correlations among other constructs (Fornell \& Larcker, 1981). Therefore, the CFA results show a satisfying support for the following SEM analysis.

\subsection{Structural Model}

Our structural model contains six constructs (PDS, environmental turbulence, institutional pressure, product innovation, international marketing competence, and export performance), 12 observable indicators and 195 observations. Model fit measures of the SEM model are: $\chi^{2}=318.63$, RMSEA $=.05, \mathrm{CFI}=.92$, SRMR $=.06$, $\mathrm{TLI}=.90$. Table 4 summarizes the results of the direct and indirect effects of the structural paths.

Table 4. Structural Model Results: Antecedents and Consequences of the PDS

\begin{tabular}{|c|c|c|c|}
\hline & Hypothesis & $\begin{array}{c}\text { Path } \\
\text { Coefficient } \\
(\beta)\end{array}$ & $\begin{array}{c}\text { Significance } \\
(Z \text { - value })\end{array}$ \\
\hline Environmental & H1.1: Market Turbulence $\rightarrow$ PDS & $.30 * *$ & 3.16 \\
\hline Turbulence & H1.2: $\quad$ Tech Turbulence $\rightarrow$ PDS & -.09 & $-0.93^{\text {n.s. }}$ \\
\hline \multirow{3}{*}{ Institutional Pressure } & H2.1: $\quad$ Regulatory Pressure $\rightarrow$ PDS & -.04 & $-0.36^{\text {n.s. }}$ \\
\hline & H2.2: $\quad$ Normative Pressure $\rightarrow$ PDS & -.03 & $-0.15^{\text {n.s. }}$ \\
\hline & H2.3: Cognitive Pressure $\rightarrow$ PDS & .06 & $0.33^{\text {n.s. }}$ \\
\hline \multirow{2}{*}{ Product Innovation } & H3.1: $\quad$ Exploitation $\rightarrow$ PDS & $.38 * *$ & 3.87 \\
\hline & H3.2: $\quad$ Exploration $\rightarrow$ PDS & .05 & $0.28^{\text {n.s. }}$ \\
\hline \multirow{4}{*}{$\begin{array}{l}\text { International } \\
\text { Marketing } \\
\text { Competence }\end{array}$} & H4.1: $\quad$ Marketing Capability $\rightarrow$ PDS & $.55 * * *$ & 4.10 \\
\hline & H4.2: $\quad$ Branding Capability $\rightarrow$ PDS & $.36 * * *$ & 3.67 \\
\hline & H5.1: Marketing Capability $\rightarrow$ PEF & $.31 * *$ & 3.89 \\
\hline & H5.2: Branding Capability $\rightarrow$ PEF & $.19 * *$ & 2.85 \\
\hline Product & H6: $\quad$ PDS $\rightarrow$ Export performance (PEF) & $.16^{* *}$ & 2.89 \\
\hline Differentiation & H7.1: $\quad$ PDS $\rightarrow$ PEF (emerging) & .09 & 1.73 \\
\hline Strategy & H7.2: $\quad$ PDS $\rightarrow$ PEF (developed) & $.42 * * *$ & 4.56 \\
\hline \multirow{6}{*}{ Control Variables } & Firm size $\rightarrow$ & & \\
\hline & PDS & .07 & $1.33^{\text {n.s. }}$ \\
\hline & Export performance & .02 & $1.02^{\text {n.s. }}$ \\
\hline & Export experience $\rightarrow$ & & \\
\hline & PDS & -.02 & $-1.34^{\text {n.s. }}$ \\
\hline & Export performance & .06 & $0.93^{\text {n.s. }}$ \\
\hline \multirow{6}{*}{ Model fits } & $\chi^{2}$ & $1875.87 * *$ & \\
\hline & RMSEA & .05 & \\
\hline & CFI & .92 & \\
\hline & SRMR & .06 & \\
\hline & TLI & .90 & \\
\hline & $* * p<.05 ; * * * p<.01 ;$ n.s. non-significant & & \\
\hline
\end{tabular}

Our proposed model is generally supported by the path coefficients. Market turbulence is positively related to the $\operatorname{PDS}(\beta=.30, \mathrm{p}<.01)$ while technological turbulence does not show significant impact on PDS, which partly supports H1. Institutional pressure fails to show a significant impact on PDS adoption, thus H2 is not supported. As for product innovation, exploitive innovation is positively correlated with PDS adoption $(\beta=.38, p<.01)$ while explorative innovation does not show significant impact, which partly supports H3. International marketing competence shows significant impact on PDS adoption $(\beta=.55, \mathrm{p}<.01)$ as well as export performance $(\beta=.31, \mathrm{p}<.01)$. Meantime, branding capability positively influences PDS $(\beta=.36, \mathrm{p}<.01)$ and export performance $(\beta=.19, \mathrm{p}<.01)$, which supports H4 and H5. Meanwhile, the PDS significantly enhances firms' export performance $(\beta=.16, p<.01)$, supporting H6. As for control variables, we add firm size and their export experience into the proposed SEM model. Results suggest that export experience does not have significant impact on PDS nor performance, neither did firm size significantly influence the PDS mechanism.

Moderating role of export markets. As Table 4 shows, we also compared the PDS mechanism between developing and de veloped markets. When firms export to developed markets, the impact of the PDS on export performance is significantly greater compared to developing markets $(\beta=.42, \mathrm{p}<.04)$. Therefore, $\mathrm{H} 7$ is supported.

\section{Discussion and Conclusion}

Product strategy has become one of the most important topics in international marketing research (Myers et al., 2002). With the deepening of internationalization, a great number of exporters enhance export performance by improving established product characteristics, which complies with the core element of the PDS: empower business growth through optimizing products quality and uniqueness. However, whether adopting the PDS is 
beneficial to firms' export performance is still unclear. Compared to cost-leadership strategies, the PDS is especially hard for firms from emerging markets due to high costs and frequent technological change. Moreover, the particularities of cross border transactions make the PDS mechanism more vague and hard to predict.

In this paper, we aim to find appropriate explanations of the antecedents and consequences of the PDS in the context of firms from emerging markets. In specific, the research questions of this study are: (1) What factors lead firms to choose the PDS? (2) Does the PDS enhance firms' export performance? (3) Does the difference in export markets moderate the PDS mechanism?

\subsection{What Are the Effects of Antecedents of the PDS?}

Market turbulence According to the results of our SEM model, firms are more likely to adopt the PDS when the degree of turbulence in international market is high. As abovementioned, high turbulent market requires firms to provide unique and un-substitutable products in order to survive and maintain advantageous market position. The core advantage of the PDS is to provide superior quality products/services compared to competitors. In addition, the PDS can help firms to cultivate consistent and stable images on their international markets, which is particularly desirable to resist turbulence. Hence, the PDS is a more appropriate choice in a highly turbulent market.

Institutional pressure Inconsistent with $\mathrm{H} 2$, institutional positively affects PDS adoption. This insignificant result may come from two reasons: First, the degree of pressure on the institutional environment vary largely across different international markets, not all of them to prohibit the Chinese brand from choosing PDS. Especially when the firm is exporting to a market that shows less institutional pressure compared to home market, the negative impact of institutional pressure on the choice of PDS is not consistent. Second, the institutional pressure may also lead the firm to choose cost leadership strategy. This is due to the fact that the differentiated products or services offered by the emerging market firms may not meet the standards of the local institutional environment. Consequently, the added value cannot be converted to higher pricing power. Faced with this situation, emerging market exporters may rely on their own low-cost advantage and organizational efficiency to reduce prices to expand international market share.

Product innovation Results from our empirical analysis partly support the positive influence of product innovation on the PDS. While exploitative innovation represents the use and refinement of existing knowledge and skills in product development, the explorative innovation emphasizes the search and pursuit of completely new knowledge and skills in product development. Exploitative product innovation is more conservative and secure, while explorative product innovation, although it can bring higher returns, but also accompanied by higher risk. For the internationalization of emerging market firms, the exploitative innovation more realistic and effective for the PDS adoption. Although in recent years, emerging market firms' R\&D capability has made considerable progress, there are significant differences from established international firms. Therefore, the results of this study show that the utilization of exploitative product innovation has a significant effect on PDS adoption.

International marketing competence Results from our empirical model show that firms are more likely to adopt the PDS if they have superior international marketing competence. In addition, those firms with high level of international marketing competence are more likely to achieve superior export performance. As we suggested in hypothesis development, strong international marketing competence enhances a firm's international operation by positioning in foreign markets accurately, execute chosen strategy effectively, and adjust them according to market turbulence flexibly. Therefore, when firms possess strong marketing competence on marketing and branding aspects, they tend to adopt the PDS for further and sustainable development on international markets. Consistent with existing literature, strong international marketing competence can improve firms' export performance in a direct manner.

\subsection{What is the Role of the PDS for Export Performance?}

Results from our empirical model show that the PDS positively affects firms' export performance, which confirms the expected effect of the PDS. First, PDS has an irreplaceable advantage, which is confirmed in the process of emerging market firms' internationalization process. The PDS emphasizes the establishment and maintenance of differences with competitors by delivering unique and reliable information, products, distribution channels, and customer services to customers, isolating their business systems from their competitors, protecting the firm from international competing factors that may affect marginal revenue factors (Phillips, Chang, \& Buzzell, 1983). Second, we can consider the cost leadership strategy and PDS as both ends of the strategic spectrum, respectively. Two different strategies represent different competitive philosophy and both have their own advantages and disadvantages. Emerging market firms' strategic choice is a result of considering pros and 
cons of each strategy. With the deepening of the process of internationalization of emerging market firms, the disadvantages of cost-leading strategies become more and more prominent, and the effect of differentiation strategy on the internationalization process has been strengthened. As a result, PDS can enhance export performance through the establishment of a unique brand image and product characteristics to expand profit margins, and by improving customer satisfaction and loyalty to achieve sustainable de velopment. Therefore, this paper argues that PDS has a significant effect on emerging market firms'performance.

\subsection{Do Targeting Markets Affect the Impact of the PDS?}

The SEM model shows that the PDS significantly enhances firms' export performance on developed markets. However, when firms export to developing markets, there is no salient relationship between the PDS and performance. Hence, the positive effect of the PDS on export performance is more salient on developed markets compared to developing markets. We provide two possible explanations for this result. First, developed markets are featured with mature market structure and sufficient competition. Consequently, differentiation on products can lead to desirable market results as firm predicted. Thus, the PDS can play an efficient role on firms' export strategy on international markets. Second, consumers on developing markets are more price-sensitive compared to those on developed markets. Hence, compared to the PDS, adopting a price-leadership strategy is more suitable to developing markets. In addition, with the development of globalization, consumers on developing markets are exposed to products from both developed and developing markets. They prefer differentiated products from developed markets if they want to choose products with unique features. Thus, firms from emerging markets are not competitive enough compared to their competitors from developed markets from developing-market consumers' perspective. Combing these two reasons, the positive impact of PDS on export performance is more effective on developed markets.

\subsection{Practical Implications}

We provide three managerial recommendations. First, emerging market firms need to break the conservative view on PDS and distinguish the prevalence of the cost-leading strategy from its potential adverse effects on performance. The results of this study show that emerging market firms can achieve the desired export performance in the international market by adopting a differentiated strategy, rather than relying solely on cost leadership strategies. More and more cases show that over-reliance on cost leadership strategy will not only continue to compress profit margins, but also inhibits firms to establish superior brand image on international markets. PDS can help firms to cultivate competitive advantage which reflected in the higher price positioning, higher profit margins, more satisfied and more loyal customers and other aspects of accumulation. These competitive advantages are not easy to be imitated by the sustainability of competitors Second, this study suggests that emerging firms take full account of the external environment (international market turbulence and institutional pressure) and internal factors (product innovation and international marketing capabilities) in the selection of international marketing strategies. This approach provides a comprehensive analysis in the development of internationalization process as well as an effective forecast of the future development for emerging market firms. Third, the results of this study emphasize the importance of international marketing ability to the internationalization of emerging market firms and suggest that firms should join international competition by actively cultivating international marketing capabilities. As the empirical results show, international marketing capabilities can directly and significantly contribute to the growth of export performance, but also play a positive role in the formulation, implementation, adjustment of all aspects of international marketing strategies.

\subsection{Limitations and Future Research}

Our study is not without limitations. First, in this paper we concentrate on the impact of international product strategy on firms' export performance. Other than product alone, we suggest that considering other marketing factors (such as pricing, entry mode, promoting, etc.) together with the PDS is also highly necessary and promising for future research. Second, current research includes market turbulence and institutional pressure as environmental factors. Besides, legal systems, government regulations and cultural similarities between international marketing and home markets still call for further investigation. Third, in this paper we choose cross sectional data to conduct our empirical analysis. In the future, we recommend to use longitudinal data to examine the PDS mechanism in order to observe the internationalization progress of firms from emerging markets.

\section{Acknowledgement}

We would like to thank the generous support provided by Young Teacher Development Foundation of Central University of Finance and Economics (Project No. QJJ1546). 


\section{References}

Albaum, G., \& Tse, D. K. (2001). Adaptation of international marketing strategy components, competitive advantage, and firm performance: a study of Hong Kong exporters. Journal of International Marketing, 9(4), 59-81. https://doi.org/10.1509/jimk.9.4.59.19943

Aragón-Correa, J. A., García-Morales, V. J., \& Cordón-Pozo, E. (2007). Leadership and organizational learning's role on innovation and performance: Lessons from Spain. Industrial Marketing Management, 36(3), 349-359. https://doi.org/10.1016/j.indmarman.2005.09.006

Armstrong, J. S., \& Overton T S. (1977). Estimating nonresponse bias in mail surveys. Journal of Marketing Research, 14(3), 396-402. https://doi.org/10.2307/3150783

Bagozzi, R. P. (1980). Causal models in marketing. New York, NY: Wiley.

Brouthers, L. E., \& Xu, K. (2002). Product stereotypes, strategy and performance satisfaction: The case of Chinese exporters. Journal of International Business Studies, 33(4), 657-677. https://doi.org/10.1057/palgrave.jibs.8491038

Cavusgil, S. T., \& Zou, S. (1994). Marketing strategy-performance relationship: an investigation of the empirical link in export market ventures. Journal of Marketing, 58(1), 1-21. https://doi.org/10.2307/1252247

Cooper, R. G., \& Kleinschmidt, E. J. (1985). The impact of export strategy on export sales performance. Journal of International Business Studies, 16(1), 37-55. https://doi.org/10.1057/palgrave.jibs.8490441

Fornell, C., \& Larcker, D. F. (1981). Evaluating structural equation models with unobservable variables and measurement error. Journal of Marketing Research, 18(1),39-50. https://doi.org/10.2307/3151312

Ghauri, P. N., \& Cateora, P. R. (2010). International marketing. McGraw-Hill Higher Education.

Hair, J. F., Black, W. C., \& Babin, B. J., et al. (2009). Multivariate data analysis. Englewood: Prentice Hall International.

Jaworski, B. J., \& Kohli, A. K. (1993). Market orientation: antecedents and consequences. Journal of Marketing, 57(3), 53-70. https://doi.org/10.2307/1251854

Jayachandran, S., Sharma, S., \& Kaufman, P., et al. (2005). The role of relational information processes and technology use in customer relationship management. Journal of Marketing, 69(4), 177-192. https://doi.org/10.1509/jmkg.2005.69.4.177

Jiménez-Jiménez, D., \& Sanz-Valle, R. (2011). Innovation, organizational learning, and performance. Journal of Business Research, 64(4), 408-417. https://doi.org/10.1016/j.jbusres.2010.09.010

Kaleka, A., \& Berthon, P. (2006). Learning and locale: The role of information, memory and environment in determining export differentiation advantage. Journal of Business Research, 59(9), 1016-1024. https://doi.org/10.1016/j.jbusres.2006.07.002

Lado, N., Martínez-Ros, E., \& Valenzuela, A. (2004). Identifying successful marketing strategies by export regional destination. International Marketing Review, 21(6), 573-597. https://doi.org/10.1108/02651330410568024

Lages, L. F., \& Montgomery, D. B. (2004). Export performance as an antecedent of export commitment and marketing strategy adaptation: Evidence from small and medium-sized exporters. European Journal of Marketing, 38(9/10), 1186-1214. https://doi.org/10.1108/03090560410548933

Lages, L. F., Jap, S. D., \& Griffith, D. A. (2008). The role of past performance in export ventures: a short-term reactive approach. Journal of International Business Studies, 39(2), 304-325. https://doi.org/10.1057/palgrave.jibs.8400339

Moen, Ø., \& Servais, P. (2002). Born global or gradual global? Examining the export behavior of small and medium-sized enterprises. Journal of International Marketing, 10(3), 49-72. https://doi.org/10.1509/jimk.10.3.49.19540

Morgan, N. A., Katsikeas, C. S., \& Vorhies, D. W. (2012). Export marketing strategy implementation, export marketing capabilities, and export venture performance. Journal of the Academy of Marketing Science, 40(2), 271-289. https://doi.org/10.1007/s11747-011-0275-0

Myers, M. B., \& Cavusgil, S. T. (1996). Export pricing strategy-performance relationship: a conceptual framework. Advances in International Marketing, 8, 159-178. https://doi.org/10.1108/03090560210412746 
Myers, M. B., Cavusgil, S. T., \& Diamantopoulos, A. (2002). Antecedents and actions of export pricing strategy: a conceptual framework and research propositions. European Journal of Marketing, 36(1/2), 159-188.

Phillips, L. W., Chang, D. R., \& Buzzell, R. D. (1983). Product quality, cost position and business performance: a test of some key hypotheses. Journal of Marketing, 47(2), 26-43. https://doi.org/10.2307/1251491

Podsakoff, P. M., \& Organ, D. W. (1986). Self-reports in organizational research: Problems and prospects. Journal of Management, 12(4), 531-544. https://doi.org/10.1177/014920638601200408

Porter, M. E. (2011). Competitive advantage of nations: creating and sustaining superior performance. Simon and Schuster.

Powers, T. L., \& Loyka, J. J. (2007). Market, industry, and company influences on global product standardization. International Marketing Review, 24(6), 678-694. https://doi.org/10.1108/02651330710832658

Powers, T. L., \& Loyka, J. J. (2010). Adaptation of marketing mix elements in international markets. Journal of Global Marketing, 23(1), 65-79. https://doi.org/10.1080/08911760903442176

Qu, R. (2007). Effects of government regulations, market orientation and ownership structure on corporate social responsibility in China: An empirical study. International Journal of Management, 24(3), 582.

Reimann, M., Schilke, O., \& Thomas, J. S. (2010). Customer relationship management and firm performance: the mediating role of business strategy. Journal of the Academy of Marketing Science, 38(3), 326-346. https://doi.org/10.1007/s11747-009-0164-y

Tan, Q., \& Sousa, C. M. P. (2011). Research on export pricing: still moving toward maturity. Journal of International Marketing, 19(3), 1-35. https://doi.org/10.1509/jimk.19.3.1

Yap, S. P. W., \& Yazdanifard, R. (2014). Comparison on the Impact of Standardization and Adaptation on International Marketing. Journal of Research in Marketing, 3(1), 250-259. https://doi.org/10.17722/jorm.v3i1.83

Yiu, D., \& Shige, M. (2002). The Choice between Joint Venture and Wholly Owned Subsidiary: An Institutional Perspective. Organization Science, 13(6), 667-683. https://doi.org/10.1287/orsc.13.6.667.494

Zhou, L., Wu, W., \& Luo, X. (2007). Internationalization and the performance of born-global SMEs: the mediating role of social networks. Journal of International Business Studies, 38(4), 673-690. https://doi.org/10.1057/palgrave.jibs.8400282

Zikmund, W., Babin, B. J., Carr, J., \& Griffin, M. (2012). Business research methods. Cengage Learning.

Zou, S., \& Cavusgil, S. T. (2002). The GMS: A broad conceptualization of global marketing strategy and its effect on firm performance. Journal of Marketing, 66(4), 40-56. https://doi.org/10.1509/jmkg.66.4.40.18519

\section{Copyrights}

Copyright for this article is retained by the author(s), with first publication rights granted to the journal.

This is an open-access article distributed under the terms and conditions of the Creative Commons Attribution license (http://creativecommons.org/licenses/by/4.0/). 